\title{
An Unusual Presentation of Spasmoproxyvon Dependence from Manipur, India
}

\author{
Gojendra Singh ${ }^{1 *}$, Senilo Magh ${ }^{2}$
}

\section{Gojendra Singh ${ }^{1 *}$,} Senilo Magh ${ }^{2}$

'Department of Psychiatry, Regional Institute of Medical Sciences, Imphal, Manipur, INDIA.

${ }^{2}$ Department of Psychiatry, Regional Institute of Medical Sciences, Imphal, Manipur, INDIA.

\section{Correspondence}

Gojendra Singh

Assistant Professor, Department of Psychiatry Regional Institute of Medical Sciences Imphal, Manipur, INDIA. Mobile no: : 91-9862032931; 03852415019

Email: drgojendra@gmail.com

\section{History}

- Submission Date: 21-01-2017

- Revised Date: 29-04-2017

- Accepted Date: 17-07-2017

DOI : 10.5530/ijmedph.2017.3.36

Article Available online

http://www.ijmedph.org/v7/i3

\section{Copyright}

(C) 2017 Phcog.Net. This is an openaccess article distributed under the terms of the Creative Commons Attribution 4.0 International license.

\section{ABSTRACT}

We report a case of a young male Opioid user who was taking an exceptionally high dose of Spasmoproxyvon (SP). Investigations did not reveal any significant deleterious effect to his health although he was using five times more than the documented toxic dose.

Key words: Opioid User, Spasmoproxyvon, Opioid Dependence.

\section{INTRODUCTION}

Manipur, one of the hilly Northeastern Indian states, is geographically close to the notorious drug-producing 'golden triangle.' The state shares a common international border with Myanmar, which is part of the Golden Triangle (Myanmar, Laos and Thailand), the world's second largest illicit opium producing country. ${ }^{2}$ Manipur characterized by ethnic conflict, armed civil insurgency, heavy military presence and high unemployment increased the vulnerability of local youth to drug use. ${ }^{3}$ It has been estimated that there are about 40,000-50,000 drug addicts in the state of whom nearly half are injecting drug users (IDU). ${ }^{4,5}$ Approximately $2 \%$ of the population of $\mathrm{Ma}$ nipur injects drugs. ${ }^{6}$

Dextropropoxyphene and its various combinations are being sold in India in the trade name of Spasmoproxyvon, Relipen, Spasmocip etc. Spasmo-proxyvon is a popular brand of antispasmodic from Wockhardt which contains paracetamol (acetaminophen) $400 \mathrm{mg}$, dicyclomine $10 \mathrm{mg}$ and dextropropoxyphene 100 mg. $^{7}$

Opioid dependence is characterised by a strong desire to take opioid, difficulties in controlling substance-taking behaviour, physiological withdrawal state, tolerance to opioid, neglect of alternative pleasure or interests and persistent use of opioid despite clear evidence of overtly harmful consequences.

We report a case of a client taking exceptionally high dose of Spasmoproxyvon (SP) tablets.

\section{CASE HISTORY}

A 22 year old unmarried male presented to the outpatient department of Psychiatry with his mother for de-addiction. He was the elder of two siblings of a single mother. He had stopped his studies after scrapping through higher secondary schooling due to this habit and was unemployed at the time of consultation.

Having taken his last dose in the morning he came to the hospital dysphoric about his present life and wanting to change. He had tried several times on his own to stop the drugs but failed. He was well oriented to time, place and person. Attention and memory were normal, judgment was intact. On examination his pupil was slightly constricted suggestive of opioid intoxication. His vitals were stable and systemic examination showed no abnormality. He had been taking 56-60 tablets of Spasmoproxyvon (SP) and 4 tablets of Nitrazepam (N10) per day for the past three years; 28-30 tablets of SP with 2 tablets of N10 in the morning and evening daily costing him 300-500 rupees in a day.

He was introduced to SP at the age of 14 by his friends and soon got hooked to it. He started with 2 tablets in the morning followed by another dose in the evening. Three months later, out of curiosity he tried N10 with SP through his friends and then started cocktailing the two for a greater 'kick'. He would take 2 tablets of N10 with 4-5 tablets of SP two times per day. With time, he raised the dose of SP tablet to the present dose of 28-30 tablets of SP per intake (total of 56-60 in a day) but never dared to inject for fear of HIV. On multiple occasions he was arrested by the police for possession of illicit drugs. He also consumed alcohol and smoked tobacco occasionally. There was no history of substance use in the family.

As per the International Classification of Diseases-10 diagnostic criteria (ICD-10) a diagnosis of opioid dependence (F11.2) was made. He was then admitted in the de-addiction ward for detoxification and further management.
Cite this article : Singh G, Magh S. An Unusual Presentation of Spasmoproxyvon Dependence from Manipur, India. Int J Med Public Health. 2017;7(3):178-80. 


\section{Investigation}

Liver function test: total bilirubin - $0.5 \mathrm{mg} / \mathrm{dl}$ (0.1-1.0), aspartate transaminase - 70IU (17-59), alanine transaminase - 141IU (21-72), alkaline phosphatase - 456IU (30-120), gamma glutamyl transpeptidase 438IU(15-73). Other routine laboratory investigations; complete blood count, kidney function test, Chest X-ray and electrocardiogram were normal. Serum for Hepatitis B, C and HIV were non-reactive.

Ultrasonography of the whole abdomen showed enlarged liver measuring $19 \mathrm{cms}$ with slight increase in echotexture suggestive of mild fatty change.

\section{Management}

He was started on tablet Buprenorphine $2 \mathrm{mg}$ was given sublingually thrice daily, Chlordiazepoxide 10mg; 2-1-2 tablets per day, injection Lorazepam $4 \mathrm{mg}$ at bedtime with other supportive medications. Medications were gradually tapered and stopped as his withdrawal signs and symptoms (lacrimation, rhinorrhoea, sweating, diarrhoea, yawning, muscle cramps) improved. Relapse prevention, motivational enhancement and interpersonal therapy were administered concurrently. He was registered under opioid substitution therapy (OST) as per his preference and sent home on day 15 of admission under OST twice daily with other supportive medications. The client has been following up regularly in the outpatient department without any relapse and is psychosocially functioning well.

\section{DISCUSSION}

Dextropropoxyphene is an opioid analogue structurally related to methadone. Its L-isomers is responsible for antitussive actions whereas analgesic effect resides in the $\mathrm{D}$-isomers by actions on 'mu'-receptors but less selective than morphine. Due to the selective action on the 'mu'-receptor, it has high addictive potential. Serum peak level is reached within one hour following rapid oral absorption.

It is metabolized in liver by $\mathrm{N}$-demethylation to produce a more active metabolite norpropoxyphene. The half-life of propoxyphene is 6 to 12 hours whereas norpropoxyphene is 37 hours. Due to prolonged halflife, norpropoxyphene is believed to play a role in the prolonged clinical course following an overdose. ${ }^{8-10}$

Normally the therapeutic concentration for dextropropoxyphene is about $0.4 \mathrm{mg} / \mathrm{L}$, and plasma concentration in serious toxicity is found to be over $1 \mathrm{mg} / \mathrm{L} .{ }^{11}$ Convulsions and delirium are the major effects of overdose. Adverse effects on chronic use comprise impairment of mental performance, drowsiness, lethargy, blurred vision, miosis, decreased appetite, inhibition of the cough reflex (antitussive effect), respiratory depression, and constipation. ${ }^{12}$

Dicyclomine (dicloverine) is a synthetic tertiary amine, which is a muscarinic receptor antagonist. It has a direct, smooth muscle relaxant action, in addition to antis-pasmodic and antiemetic properties. Atropinic side effects are usually not present at antispasmodic doses. It is commonly used for treating irritable bowel syndrome, motion sickness, morning sickness, rectal urgency, abdominal cramps, dysmenorrhoea, etc. ${ }^{6}$ Overdose can cause atropinic effects such as dry mouth, dilated pupils, palpitations, psychotic behaviour, delirium, hallucinations, CVS collapse and respiratory depression.

Acetaminophen (paracetamol) is a para-aminophenol derivative, and is an analgesic- antipyretic with poor anti- inflammatory action. It has a central analgesic action (raising the pain threshold). Plasma half-life is about 2-3 hours, and effective oral dose lasts 3-5 hours. It is one of the most commonly used over-the-counter analgesic- antipyretic drugs, used in doses of 0.5-1 gm three times a day. Adverse effects are rare, as the drug is well tolerated, but chronic use can cause analgesic nephropa- thy. Acute poisoning can cause centrilobular hepatic necrosis, hypoglycaemia, etc. Fulminant hepatic failure and death are likely if the plasma levels are above $200 \mathrm{mcg} / \mathrm{ml}$ at $4 \mathrm{hrs}$, and $30 \mathrm{mcg} / \mathrm{ml}$ at $15 \mathrm{hrs}$ of ingestion. ${ }^{13}$

The maximum doses for the constituents of Spasmo-Proxyvon areasfollows:

- Acetaminophen: 2-4 grams/day

- Dextropropoxyphene napsylate: $600 \mathrm{mg} /$ day

- Dicyclomine: No available safety data for doses above $80 \mathrm{mg} /$ day. ${ }^{13}$

Spasmoproxyvon dependent clients generally take about 15-30 tablets per day to stay high. Our client was using 56-60 tablets in a day, a dose much higher than the above toxic dose on a daily basis for the past three years i.e. 12gms of Acetaminophen, 3000mg of Dextropropoxyphene napsylate and 300mg of Dicyclomine. Interestingly, his liver function tests also did not reveal much derangement as expected and ultrasonography of the whole abdomen showed features suggestive of mild fatty change only. This can be explained by the higher regenerative capacity of the hepatocytes in the young.

Opioids, at and above pain-relieving doses induce euphoria, sometimes called a "rush" followed y a profound sense of tranquility which may last hours. Adaptation of opioid receptors occurs quite readily after chronic opioid administration by decreasing their sensitivity to it. ${ }^{14}$ Similar mechanisms may play a role to increase the level of tolerance and decrease the damage to the rest of the body.

He was introduced to psychoactive substances by his friends at the age of 14 years. Most substance users initiates substance use for enjoyment or out of curiosity and are usually introduced to these substances mostly by their friends in their student life. ${ }^{6,15}$ Friends may influence a person to start using substances by making them available, providing an example or defining the nature of the physiological experience. ${ }^{16}$ Experimenting with drugs, however, is particularly dangerous because recreational use may progress to more problematic use and dependence.

Over dose from SP tablet resulting in death is an occasional occurrence in this region of the country. Usually such patients are found dead at the spot. Autopsy findings of such patients showed cyanosis of finger nails, congestion of kidneys and lungs and gastric mucosa. ${ }^{17,18}$

\section{CONCLUSION}

From the literature any intake of the drug at a dose higher than its maximum dosage can cause adverse effects to the body but this is one rare case showing no such effects.

\section{REFERENCES}

1. Singh AD, Kaul RK, Sharma SG, Singh KC, Singh YM, Singh TB, et al. Survey of drug abuse in Manipur state - A report. Manipur: Committee for Prevention of Drug Abuse (COPDA), Indian Medical Association, Manipur State Branch; 1992.

2. Chandrasekaran P, Dallabetta G, Loo V, Rao S, Gayle H, Alexander A. Containing HIV/AIDS in India: the unfinished agenda. The Lancet infectious diseases. 2006;6(8):508-21.

3. Di Natale R. Project ORCHID and beyond: responding to intravenous drug use and HIV transmission in Northeast India. Dev Bull. 2006;69:83-6.

4. Kermode $M$, Longleng $V$, Singh BC, Hocking J, Langkham B, Crofts N. My first time: initiation into injecting drug use in Manipur and Nagaland, north-east India. Harm Reduction Journal. 2007 Dec 5;4(1):19-60

5. United Nation Office On Drugs And Crime (UNDOC). Executive summary-drug use in the Northeastern states of India. Available at http://www.unodc.org/pdf/ india/drug_use/executive_summary pdf. Accessed August 16, 2014.

6. Ningombam S, Hutin Y, Murhekar MV. Prevalence and pattern of substance use among the higher secondary school students of Imphal, Manipur, India. Natl Med J Ind. 2011;24(1):1-15.

7. Available at: URL:http://www.drugsupdate.com/brand/generic/Dicycloverine\%20Hyrochoride/28652/none/9. Accessed June 26, 2016.

8. Wolen RL, Gruber CM, Kiplinger GF, Scholz NE. Concentration of propoxyphene in human plasma following oral, intramuscular, and intravenous administration. 
Toxicology and applied pharmacology. 1971;19(3):480-92

9. Bellville JW, Seed JC. A comparison of the respiratory depressant effects of dextropropoxyphene and codeine in man. Clinical Pharmacology \& Therapeutics. 1968;9(4):428-34.

10. Verebely K, Inturrisi CE. Disposition of propoxyphene and norpropoxyphene in man after a single oral dose. Clinical Pharmacology \& Therapeutics. 1974 Mar 1;15(3):302-9.

11. Dart RC. Medical Toxicology. Lippincot Williams \&Wilkins, Philadelphia; $3^{\text {rd }}$ edn 2003. p. 132-35

12. Miller RL. Propoxyphene in the Encyclopedia of Addictive Drugs. Greenwood Press, London; 2002. p. 390-93.

13. Brunton L, Parker K, Blumentel D, Buxton L. Goodman \& Gillman's Manual of Pharmacology and Therapeutics. McGrawHill; 11 edn, 2008. p. 445.
14. Stephen M. Stahl. Stahl's essentital psychopharmacology. Cambridge University press; $4^{\text {th }} e d n, 2013$. p. 559-60.

15. Kapil U, Goindi G, Singh V, Kaur S, Singh P. Consumption of tobacco, alcohol and betel leaf amongst school children in Delhi. Indian journal of pediatrics. 2005;72(11):993-.

16. NIHFW, NACO. Annual Sentinel Surveillance for HIV Infection in India, 2006. New Delhi: National Institute of Health and Family Welfare (NIHFW), National AIDS Control Organization (NACO); 2007. p. 59-62.

17. Swain R, Singh SR, Krishna K, Behera C, Mallick S, Bhardwaj DN. Fatal Dextropropoxyphene Poisoning An Autopsy Study of 11 Cases. Journal of Indian Academy of Forensic Medicine. 2014;36(1):34-7.

18. Raghava SV, Kautilya DV, Havanur B, Devadass PK. Fatality from spasmoproxyvon® addiction: A few cases. J Indian Soc Toxic. 2010; 6(2): 47-49.

Cite this article : Singh G, Magh S. An Unusual Presentation of Spasmoproxyvon Dependence from Manipur, India. Int J Med Public Health. 2017;7(3):178-

80 . 